\title{
Strength and Failure Characteristics of Saturated Sandstone Under Loading and Unloading
}

\author{
Zhenhua Zhang ( $\nabla$ zenithzhang@sina.com ) \\ Hefei University of Technology \\ Huayan Yao \\ Hefei University of Technology \\ Hongguo Li \\ Hefei University of Technology \\ Hanbin Bian \\ University of Lille: Universite de Lille \\ Dayong Zhu \\ Hefei University of Technology
}

\section{Research Article}

Keywords: saturated sandstone, strength, failure characteristics, triaxial loading and unloading

Posted Date: April 19th, 2021

DOI: https://doi.org/10.21203/rs.3.rs-409372/v1

License: (c) (i) This work is licensed under a Creative Commons Attribution 4.0 International License.

Read Full License 


\title{
Strength and failure characteristics of saturated sandstone under loading and unloading
}

\author{
Huayan Yao ${ }^{1}$, Zhenhua Zhang ${ }^{1}$, Hongguo Li ${ }^{1}$, Hanbin Bian², Dayong Zhu ${ }^{1}$ \\ 1.School of Civil Engineering, Hefei University of Technology, Hefei 230009, China \\ 2. Laboratory of Civil Engineering and Geo-Environment (LGCgE), University of Lille, Villeneuve d'Ascq 59650, \\ France
}

\begin{abstract}
Water has effects on the strength and failure characteristics of the sandstone in natural environment. Conventional triaxial compressive or unloading confining pressure experiments were conducted on sandstone specimens. Experimental results indicate that the compressive strength of sandstone decreases significantly under saturated conditions in comparison with dry conditions, the strength parameters of saturated specimens under unloading confining pressure are also lower than those of dry rock samples; for the sandstone with the same water content, the strengths under triaxial unloading confining pressure is slightly higher than those under triaxial compressive condition; compared with the stress path of triaxial compression, the stress path of unloading confining pressure makes cracks propagate more easily along the axial direction, and the angle between fracture surface and axial direction is smaller. Under triaxial unloading confining pressure, there failure modes of dry sandstone are tension failure and shear failure, while that of saturated sandstone is mainly shear failure. In the process of water saturation, the bond and friction characteristics between grain particles are degraded due to water weakening the cementation between the grain particles and softening grains boundary, and the expansion of clay minerals in the sandstone, which leads to the decrease of macroscopic mechanical strengths.
\end{abstract}

Keywords: saturated sandstone; strength; failure characteristics; triaxial loading and unloading

\section{Introduction}

There are many excavations of high steep slopes or underground caverns in the course of constructions of numerous large-scale hydropower, mining and transportation projects. The failure or instability of rock mass caused by unloading due to the excavations is a very common phenomenon in rock engineering, which brings adverse influence on the constructions (Cai and Kaiser 2005; Fan et al. 2016). Under the excavation disturbance, the original mechanical equilibrium state of rock mass is broken, which causes redistribution of rock mass stress, and one or two principal stresses are removed, resulting in the failure of the rock mass (Miao et al. 2011; Fu et al. 2018; Shen \& Barton 2018).

Variations in mechanical properties of rocks due to different stress paths have been confirmed by many researchers (Swansson and Brown 1971; Ganne and Vervoort 2007; Yang et al. 2011; Taheri et al. 2016). In recent years, more and more attentions have been paid to the theoretical research and engineering application of strength and failure characteristics of rocks under unloading conditions. Many experiments with unloading stress have been carried out aiming at different problems. For examples, Chen et al. (2008) discussed the strength criterion under the condition of unloading confining pressure. Yao et al. (2018) have investigated the failure characteristics of schist under triaxial loading and unloading confining pressure conditions, and showed that the stress paths have a great influence on the fracturing mode of schist. Li et al. (2010) have studied unloading nonlinear mechanical characteristics of excavated jointed rock mass by a series of model tests and triaxial loading and unloading tests and rheological tests of sandstone samples. Some experiments showed the violent (dynamic) ejection of rock fragments and arcshape fractures near the free face were often observed under true triaxial unloading condition (Wang et al. 2020). Moreover, the effects of unloading mode or path (Li et al. 2014), unloading rate (Xu et al. 2019), unloading stress levels (Cong et al. 2020) on rock mechanical properties were all considered in their studies. All the studies mentioned above show that there are great differences in mechanical responses and fracture mechanisms of rocks under unloading and loading conditions.

* Corresponding author, Zhenhua Zhang, email: zenithzhang@sina.com 
At the same time, water is the most active and unavoidable factor in the stability of geotechnical engineering. Its interaction with rocks will change the physical, chemical and mechanical properties of the rock, and then leads to variations in the strength and failure characteristics of the rocks (Newbrough and Gammons 2002; Ciantia et al. 2015; Maruvanchery and Kim 2019). Therefore, it is necessary to consider the influence of water on rock engineering under unloading conditions (Zhang et al. 2020). Considering the role of groundwater, Chen et al. (2018) have also performed the studies of seepage characteristics under unloading conditions. It shows that the influence of unloading process of fractured rock mass on permeability coefficient should not be ignored. However, at present, there is not much literature considering the influences of groundwater on the mechanical properties of rock under the unloading condition. The differences of mechanical properties of saturated rock, such as strength deterioration and failure modes, under different stress paths are not clearly understood. In this paper, loading and unloading triaxial tests of sandstone specimens under dry and saturated conditions are carried out and the results of the tests are discussed to analyze the effect of water on the strength and failure characteristics of sandstone under loading and unloading.

\section{Samples preparation and experimental methodology}

\subsection{Sample Preparation}

The rock samples were taken back and processed into cylindrical specimens with a diameter of about $50 \mathrm{~mm}$ and a height of about $100 \mathrm{~mm}$ (Fig. 1).

The test rock samples are feldspar quartz sandstone. The main components obtained using Xray Diffraction are shown in Table 1. The samples are contact-pore cementation, mainly composed of quartz, feldspar and calcite, et al., the cements are mainly siliceous, with a small amount of iron, clay and calcium. The orthogonal polarization photograph is shown as Fig. 2.

The saturated sandstone specimens were obtained by soaking the natural specimens in distilled water for $48 \mathrm{~h}$. The natural specimens are dried at $105^{\circ} \mathrm{C}$ for 24 hours and then cooled to room temperature as dry specimens for future tests.

Table 1 Main mineral composition of the sandstone

\begin{tabular}{|c|c|c|c|c|}
\hline Mineral & Quartz & Calcite & Feldspar & Dolomite \\
\hline Content $(\%)$ & 48.61 & 21.74 & 26.50 & 3.15 \\
\hline
\end{tabular}

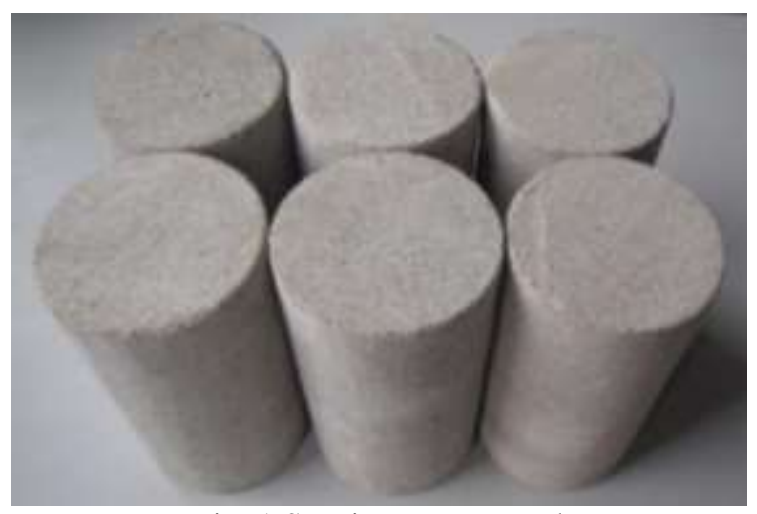

Fig. 1 Specimens prepared 


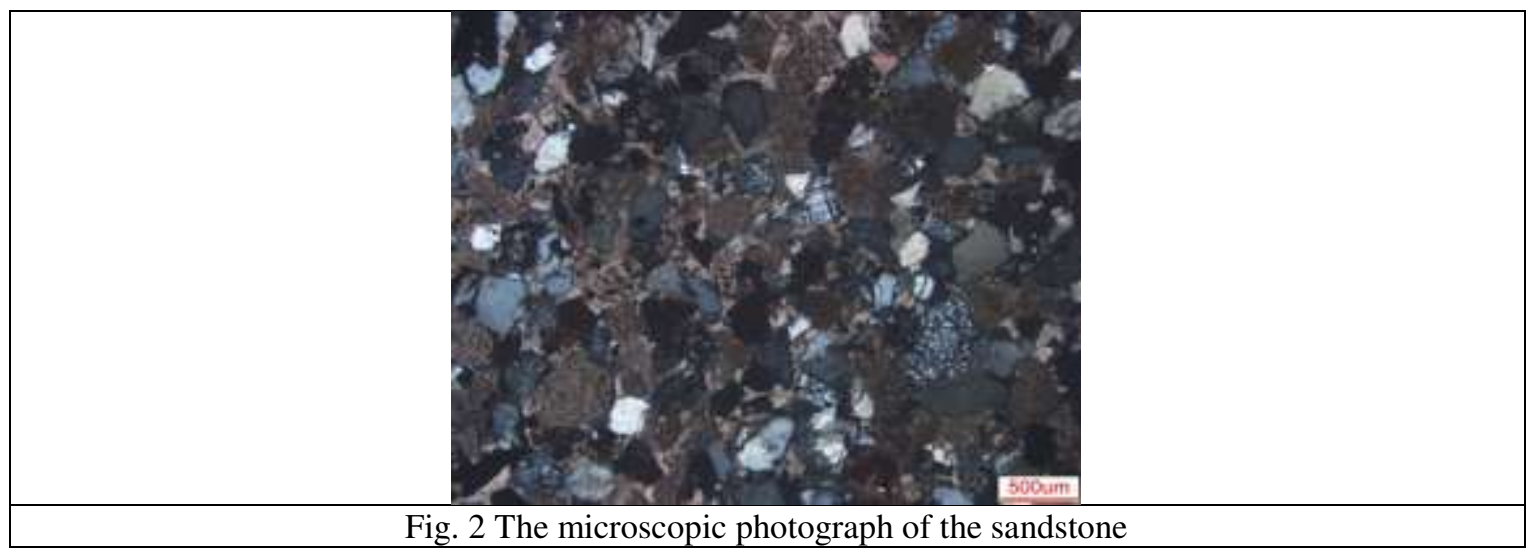

\subsection{Experimental methodology}

The experiments include conventional triaxial compressive tests of dry and saturated sandstone specimens, and triaxial unloading confining pressure tests of dry and saturated sandstone specimens.

In the conventional triaxial compressive tests, firstly increasing both axial stress $\sigma_{1}$ and confining pressure $\sigma_{3}$ simultaneously with the loading rate of $0.5 \mathrm{MPa} / \mathrm{s}$ to the initial desired confining pressure $\sigma_{3}^{0}$, which are set to be four levels, i.e., 5, 10, 15, $20 \mathrm{MPa}$. Then keeping $\sigma_{3}$ constant, and $\sigma_{1}$ was slowly increased to failure with the loading rate of $0.01 \mathrm{~mm} / \mathrm{s}$. The graphical of stress path is shown in Fig.3(a).

The basic procedure of unloading confining pressure tests was described as follows (Fig.3(b)):

(1) Increasing both axial stress $\sigma_{1}$ and confining pressure $\sigma_{3}$ simultaneously with the loading rate of $0.5 \mathrm{MPa} / \mathrm{s}$ to the initial desired confining pressure $\sigma_{3}^{0}$, which are set to be five levels, i.e., 10, 15, 20, 25, and $30 \mathrm{MPa}$.

(2) Keeping $\sigma_{3}$ constant, and $\sigma_{1}$ was slowly increased with the loading rate of $0.01 \mathrm{~mm} / \mathrm{s}$ to a certain value before the rock failure. The value of the stress $\sigma_{1}$ was taken between uniaxial compressive strength and triaxial compressive strength under the confining pressure $\sigma_{3}$.

(3) Decreasing the confining pressure $\sigma_{3}$ slowly with the loading rate of $0.5 \mathrm{MPa} / \mathrm{s}$ until a failure occurred in the sample with constant $\sigma_{1}$.

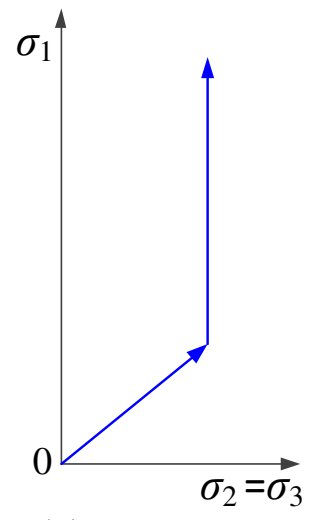

(a)

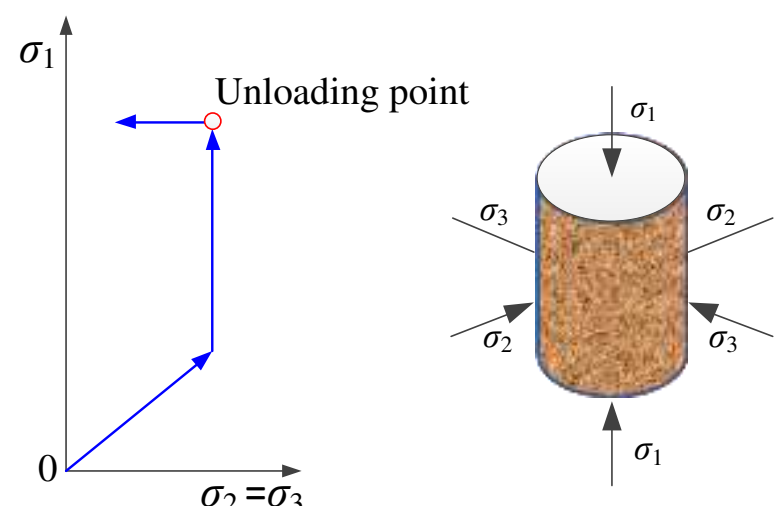

(b)

Fig.3 Graphical of stress paths:(a) conventional triaxial loading test; (b) unloading confining pressure.

\section{Test results}

\subsection{Peak compressive strength}

The peak compressive strengths of sandstone specimens under loading and unloading conditions listed in Table 2 increase with the increase of confining pressures for all experiments, either triaxial compressive tests or triaxial unloading tests. Specifically, for the dry specimens on which triaxial compressive tests performed, the peak compressive strength $\sigma 1$ is $99.76 \mathrm{MPa}$ under 
confining pressure of $5 \mathrm{MPa}$, and it reaches $182.06 \mathrm{MPa}$ under confining pressure of $20 \mathrm{MPa}$; it changes from $75.59 \mathrm{MPa}$ when the confining pressure unloading to $1.2 \mathrm{MPa}$ to $126.23 \mathrm{MPa}$ when the confining pressure unloading to $8.13 \mathrm{MPa}$. As the dry sandstone samples, the same laws of the variations in the peak compressive strengths happens on the saturate sandstone samples.

Table 2 Peak compressive strengths and shear strengths

\begin{tabular}{|c|c|c|c|c|c|c|}
\hline \multirow[t]{2}{*}{ Sample state } & \multirow{2}{*}{$\begin{array}{l}\text { Testing } \\
\text { method }\end{array}$} & \multirow[t]{2}{*}{$\begin{array}{c}\text { Sample } \\
\text { No }\end{array}$} & \multicolumn{2}{|c|}{$\begin{array}{c}\text { Stress state at failure } \\
(\mathrm{MPa})\end{array}$} & \multirow{2}{*}{$\begin{array}{c}\text { Cohesion } \\
c / \mathrm{MPa}\end{array}$} & \multirow{2}{*}{$\begin{array}{l}\text { internal friction } \\
\text { angle } \varphi /^{\circ}\end{array}$} \\
\hline & & & $\sigma_{3}$ & $\sigma_{1}$ & & \\
\hline \multirow{4}{*}{ dry } & \multirow{8}{*}{$\begin{array}{c}\text { Triaxial } \\
\text { compression }\end{array}$} & G1 & 5 & 99.76 & \multirow{4}{*}{14.46} & \multirow{4}{*}{44.48} \\
\hline & & G6 & 10 & 120.41 & & \\
\hline & & G3 & 15 & 157.54 & & \\
\hline & & G4 & 20 & 182.06 & & \\
\hline \multirow{4}{*}{ saturated } & & S1 & 5 & 81.55 & \multirow{4}{*}{14.08} & \multirow{4}{*}{38.41} \\
\hline & & S2 & 10 & 94.19 & & \\
\hline & & S3 & 15 & 130.57 & & \\
\hline & & S4 & 20 & 140.76 & & \\
\hline \multirow{8}{*}{ dry } & \multirow{18}{*}{$\begin{array}{l}\text { Triaxial } \\
\text { unloading }\end{array}$} & G7 & 1.22 & 75.59 & \multirow{8}{*}{14.98} & \multirow{8}{*}{46.21} \\
\hline & & G8 & 5.75 & 100.50 & & \\
\hline & & G9 & 8.13 & 126.23 & & \\
\hline & & G12 & 2.17 & 80.26 & & \\
\hline & & G13 & 2.12 & 105.34 & & \\
\hline & & G14 & 8.01 & 131.42 & & \\
\hline & & G15 & 15.08 & 157.74 & & \\
\hline & & G16 & 16.40 & 183.79 & & \\
\hline \multirow{10}{*}{ saturated } & & S6 & 3.50 & 67.90 & \multirow{10}{*}{13.46} & \multirow{10}{*}{40.43} \\
\hline & & S7 & 4.87 & 84.36 & & \\
\hline & & S8 & 8.71 & 102.52 & & \\
\hline & & S9 & 15.07 & 119.90 & & \\
\hline & & S10 & 14.98 & 146.84 & & \\
\hline & & S12 & 2.08 & 71.22 & & \\
\hline & & S13 & 8.59 & 90.59 & & \\
\hline & & S14 & 14.18 & 111.14 & & \\
\hline & & S15 & 12.18 & 126.88 & & \\
\hline & & S16 & 20.85 & 154.00 & & \\
\hline
\end{tabular}

\subsection{Failure mode}

In conventional triaxial compressive tests, dry sandstone specimens still exhibit brittleness under low confining pressures. For example, G1 specimens failed with a multiple fractures under the confining pressure of $5 \mathrm{MPa}$, which is a combination failure mode of tension and shear (Fig.4). When confining pressure increases, shear failure occurs, for instance, the failure mode shown in Fig. 5 is a typical single-shear-surface failure mode under confining pressure of $20 \mathrm{MPa}$. In conventional triaxial compressive tests, the water-saturated sandstone specimens were easier to break into pieces. To specific, the saturated sandstone specimens under the confining pressure of 5 MPa were fragmented into many pieces (Fig. 6a), which exhibited a typical brittle failure mode; the saturated sandstone specimens under confining pressure of $10 \mathrm{MPa}$ were compressed into some pieces and some debris (Fig. 6b), which showed a shear failure mode. 

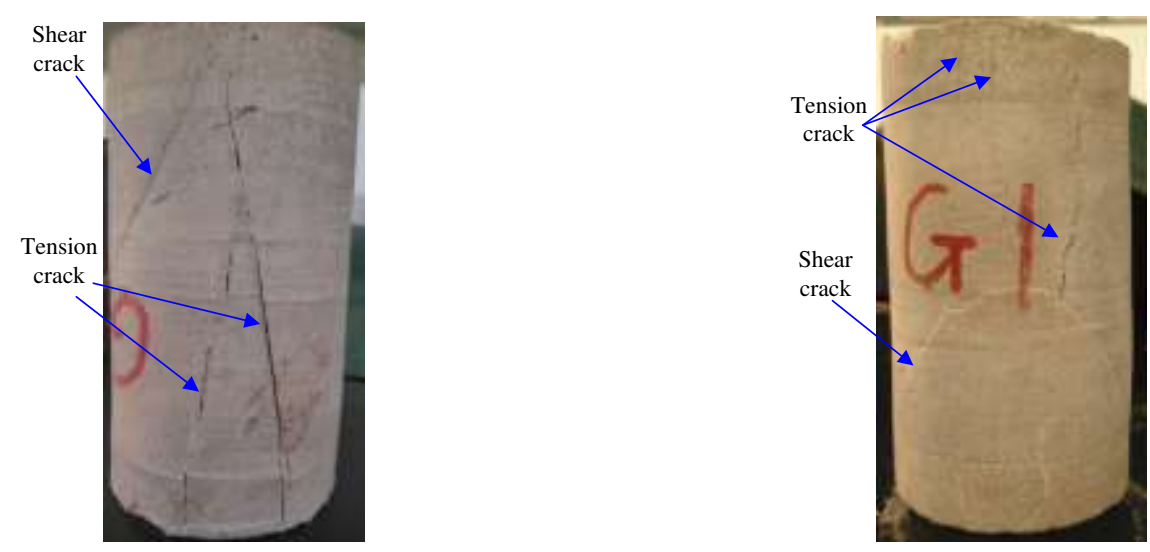

Fig. 4 Failure diagram of G1

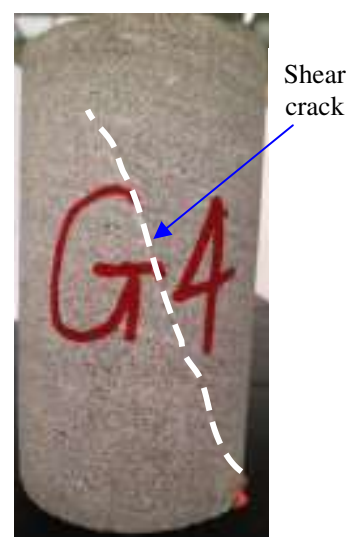

Fig. 5 Failure diagram of G4

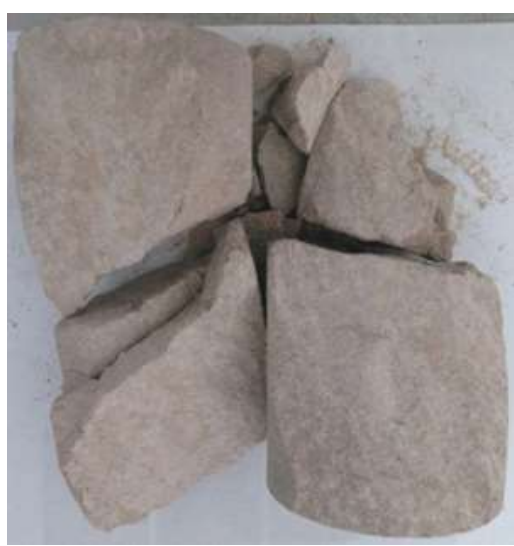

(a) S1 specimen under the confining pressure of $5 \mathrm{MPa}$

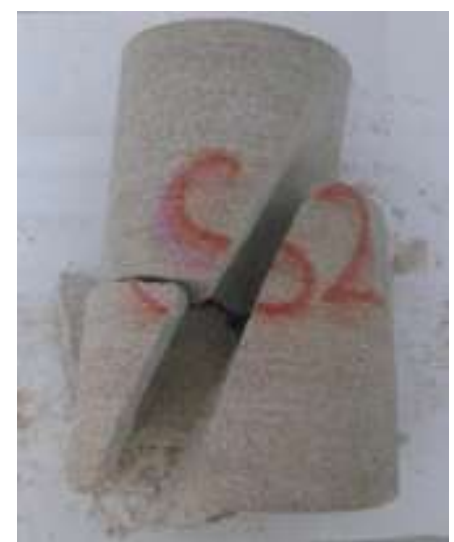

(b) S2 specimen under the confining pressure of 10 $\mathrm{MPa}$

Fig. 6 Failure diagram of the saturated specimens

In conventional triaxial unloading confining pressure tests, the dry sandstone specimens have two failure modes: multi-crack-tension failure and simple shear failure. As shown in Fig.7a that No. G7 specimen failed mainly due to several tension cracks developing in the specimens. In this case, the confining pressure is small at failure, for example, the initial confining pressure on No. G7 specimen was $10 \mathrm{MPa}$, and the confining pressure is unloaded to $1.22 \mathrm{MPa}$ when the failure occurred. It can be seen from Fig.7b that No. G8 specimen shows a single shear failure. This failure mode usually happens when the initial confining pressure is high. For instance, the initial confining pressure of No. G8 specimen was $15 \mathrm{MPa}$, and the confining pressure is reduced to 5.75 $\mathrm{MPa}$ when shear failure took place in the sample. In triaxial unloading confining pressure tests, the saturated sandstone specimens mainly take on shear failure modes. But there are also some 
differences in rupture forms. For instance, the failure mode of No. S6 specimen is single shear surface (Fig. 8a), but the failure mode of No. S7 specimen is a "Y"-shape shear fractures (Fig. 8b). Similar to the conventional triaxial loading tests mentioned above, the saturated sandstone specimens after failure were changed into more pieces than the dry sandstone specimens were. In addition, we can also see that the angle between shear failure surface and axial direction is smaller under unloading confining pressure than that under triaxial loading condition, in other word, the direction of crack propagation is almost parallel to the axial direction (Fig. 8c).

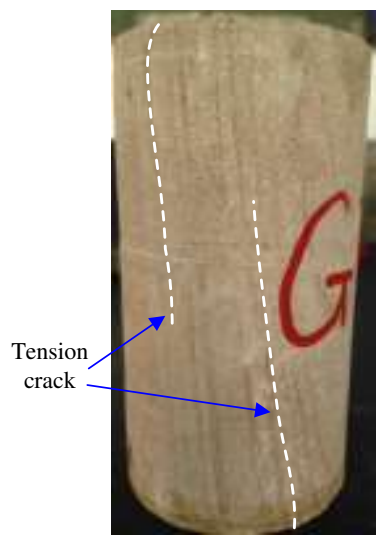

(a) G7

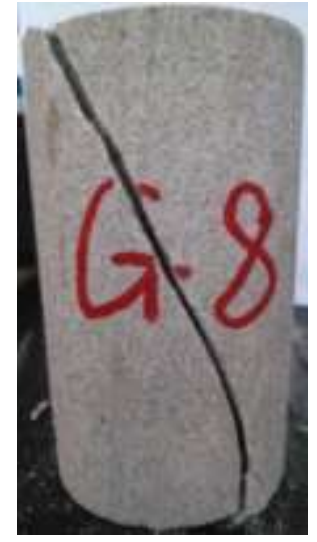

(b) G8

Fig. 7 Failure diagram of dry specimens

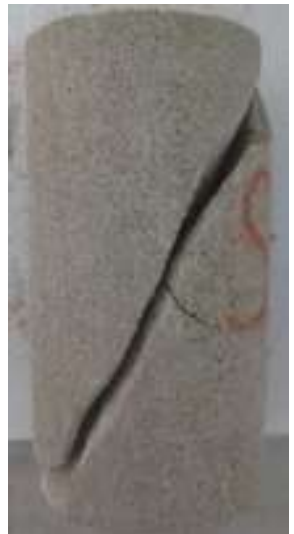

(a) S6

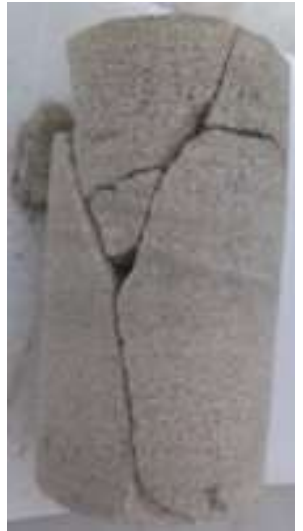

(b) S7

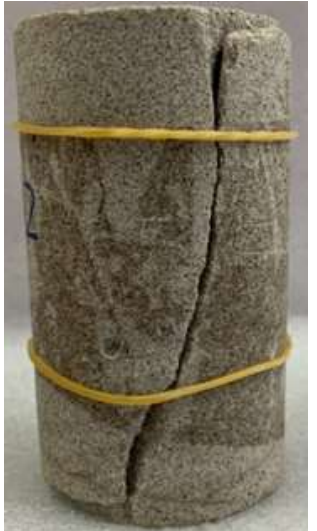

(c) $\mathrm{S} 12$

Fig. 8 Failure diagram of saturated specimens

\section{Discussions}

\subsection{Strength characteristics obtained using conventional triaxial compressive tests}

Mohr-Coulomb criterion is employed to calculate the strength parameters using the formula below:

$$
\sigma_{1}=a+b \sigma_{3}
$$

where $a$ and $b$ are fitting coefficients, $\sigma_{1}$ is the axial peak pressure, and $\sigma_{3}$ is the confining pressure. The relationship between confining pressure and axial peak pressure can be fitted through the Eq. (1), and the results of the linear fitting are shown as follows:

Dry specimens:

$$
\sigma_{1}=5.6806 \sigma_{3}+68.935\left(\mathrm{R}^{2}=0.9887\right)
$$

Saturated specimens:

$$
\sigma_{1}=4.2802 \sigma_{3}+58.265\left(\mathrm{R}^{2}=0.9478\right)
$$


The fitting results of the relationships between peak compressive strengths and confining pressures of sandstone specimens under conventional triaxial compressive tests, depicted in Fig. 9, indicate that under both dry and saturated conditions, with the increase of confining pressure, the peak strengths of the specimens increases significantly. Under the same confining pressure, the peak strengths of dry specimens are higher than those of saturated specimens. It shows that the peak compressive strength of the sandstone decreases significantly after it is saturated, which is consistent with some existing results (Erguler and Ulusay 2009, Wasantha et al. 2018).

The shear strength parameters, cohesion and internal friction angle, are determined using the formulas below:

$$
\begin{aligned}
\mathrm{c} & =(1-\sin \varphi) a /(2 \cos \varphi) \\
\varphi & =\arcsin [(b-1) /(b+1)]
\end{aligned}
$$

where $a$ and $b$ are fitting coefficients, $c$ is the coefficient and $\varphi$ is the internal friction angle. The $c$ and $\varphi$ of saturated specimens are $14.08 \mathrm{MPa}$ and $38.41^{\circ}$, respectively, while those of dry specimens are $14.46 \mathrm{MPa}$ and $44.48^{\circ}$, respectively. Compared with the dry specimens, the values of $\mathrm{c}$ and $\varphi$ of saturated specimens have decreased by $2.6 \%$ and $13.65 \%$, respectively (Table 2 ).

\subsection{Strength characteristics obtained using conventional unloading confining pressure tests}

Similarly, the test results of axial peak strengths using triaxial unloading confining pressure tests can be fitted linearly by formulas below:

Dry specimens:

$$
\sigma_{1}=6.1909 \sigma_{3}+74.544 \quad\left(\mathrm{R}^{2}=0.9261\right)
$$

Saturated specimens:

$$
\sigma_{1}=4.6899 \sigma_{3}+58.287 \quad\left(\mathrm{R}^{2}=0.8896\right)
$$

The fitting results (Fig.10) through Eqs. (6)-(7) show that the data of peak strengths of the sandstone specimens under unloading confining pressure are more discrete than those under triaxial compressive condition (Fig.9). Fig.10 demonstrates that the peak strengths of saturated sandstone increase with the increasing of confining pressures. Under the same confining pressure, the peak strength of saturated specimens is significantly lower than that of dry specimens, which is similar to those obtained using the conventional triaxial compressive tests.

The strength parameters of saturated sandstone samples under unloading confining pressure are also lower than those of dry specimens. The shear strength parameters $c$ and $\varphi$ of dry specimens are $14.98 \mathrm{MPa}$ and $46.21^{\circ}$, respectively, while those of saturated specimens are $13.46 \mathrm{MPa}$ and $40.43^{\circ}$, respectively.

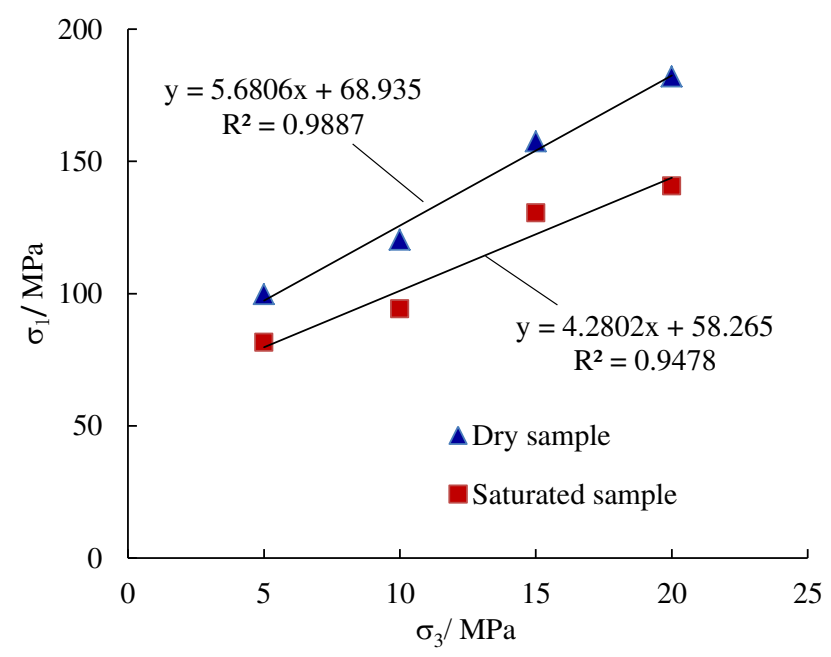

Fig. 9 Relationships between peak strength and confining pressure of saturated and dry specimens under conventional triaxial loading test 


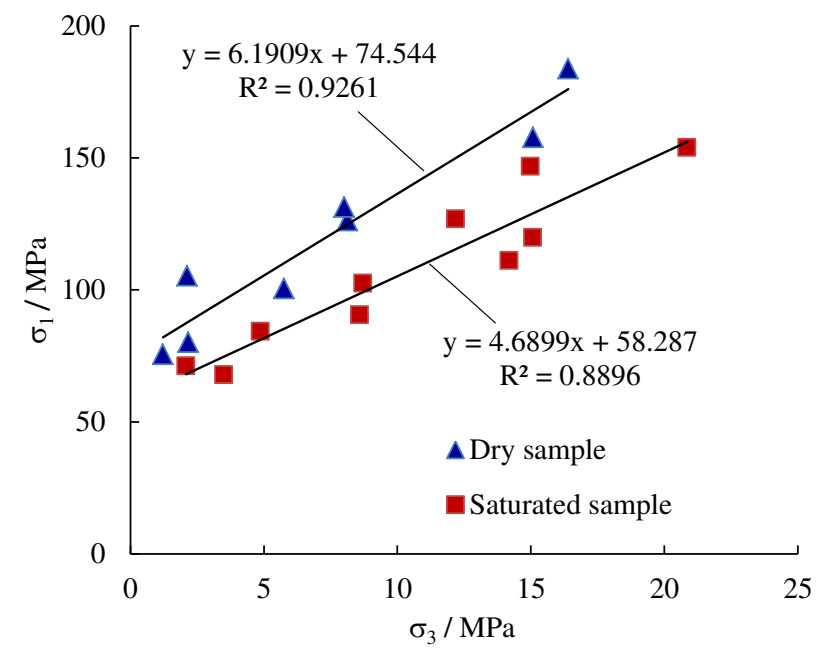

Fig. 10 Relationships between axial peak and confining pressures of the saturated and dry specimens under unloading confining pressure test

\subsection{Strength characteristic differences under conditions of triaxial compression and unloading}

The relationships between peak strengths and confining pressures of dry specimens under triaxial compression and unloading confining pressures shown in Fig.11 indicate that under the same confining pressure, the strength obtained by unloading confining pressure test is higher than that by conventional triaxial compressive test. The strength parameters $c$ and $\varphi$ depicted in Table 2 show that the cohesion $c$ increases by $3.6 \%$ and the angle of internal friction $\varphi$ increases by $3.9 \%$ under unloading confining pressure, compared with conventional triaxial loading test. However, the increases of the strength parameters are not large, that is to say, unloading confining pressure has few effects on the strengths of this type of sandstone.

From Fig.12, it can be seen that the fitted curve of the peak strengths of the saturated specimens under unloading confining pressure is above the fitted curve of those under triaxial compression, which means that under same confining pressure, the peak strength of the saturated specimen under unloading confining pressure condition is greater than that under triaxial compression. By comparison with under triaxial compressive condition, the cohesion of the saturated specimens under the condition of unloading confining pressure decreases slightly from $14.08 \mathrm{MPa}$ to 13.46 $\mathrm{MPa}$, while the internal friction angle increases slightly, from $38.41^{\circ}$ to $40.43^{\circ}$ (Table 2). In summary, unloading confining pressure also has few effects on shear strength of the saturated specimens, similar to that of dry specimens mentioned above.

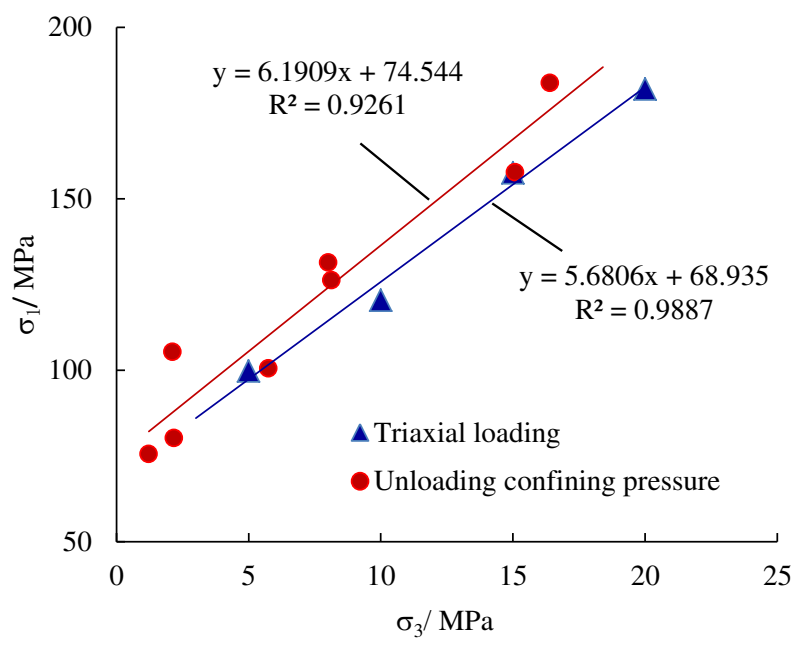

Fig. 11 Relationships between peak and confining pressure of dry specimens under triaxial loading and unloading 


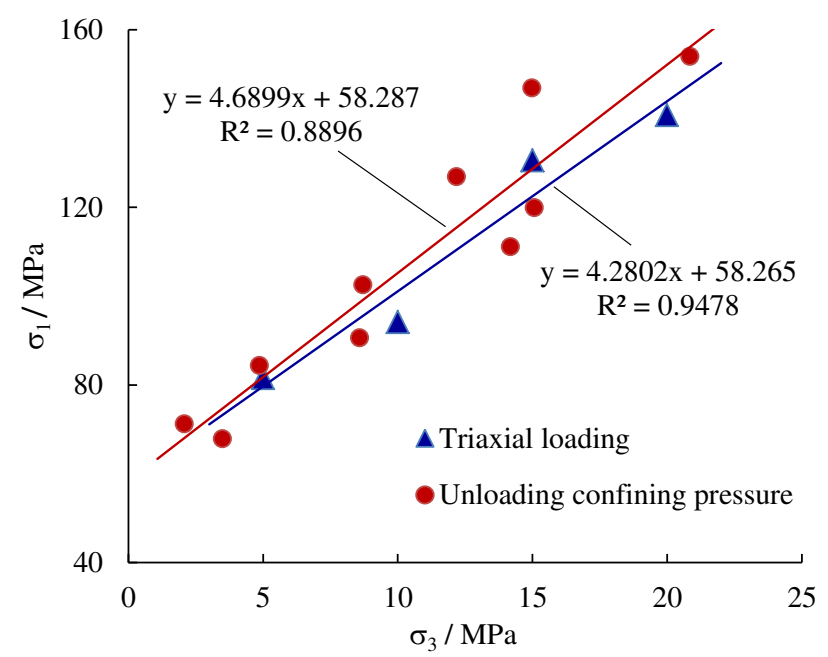

Fig. 12 Relationships between peak and confining pressure of saturated specimens under loading and unloading

\subsection{Effects of saturation with water on strengths of the sandstone under unloading conditions}

In recent years, the influences of water on rock mechanical properties have been paid attention. It's known that groundwater has physical, mechanical and chemical effects on rock mass (Ciantia et al. 2015, Maruvanchery and Kim 2019). The action of water on rock is a complex process of stress corrosion and damage. In water-bearing porous rocks, the stress corrosion of water will cause the original micro-cracks in rocks to continue to expand, grow and penetrate, and new cracks to appear (Dunning et al. 1994, Baud et al. 2000).

From the above two stress paths, e.g., triaxial compressive and unloading confining pressure, the strengths of saturated specimens decreased to varying degrees compared with that of dry specimens. The cohesion depends mainly on the cementation strength between particles due to the mineral composition and microstructures (Table 1 and Fig.2) of the sandstone. After soaking and saturating, water entered the micropore of rock and can lubricate and soften grains boundary. At the same time, water has softening effect on cementation, especially clay minerals in cements. In the process of water saturation, the expansion of mineral particles would affect the friction characteristics between particles. Finally, the macroscopic performance of the water action on the sandstone is the strength degradation in the sandstone.

\subsection{Effects of unloading condition on strength of the sandstone}

Different researchers have different opinions on the effect of unloading confining pressure on rock strength. For example, compared with the triaxial compressive condition, the cohesion increases and the internal friction angle decrease for the sandstone under unloading confining pressure condition ( $\mathrm{Li}$ et al. 2010). Results from Liu et al. (2017) showed that confining pressure unloading produces a significant reduction in coal strength. In contrast, Experiments conducted by Wang et al. (2019) with sandstone and mudstone shows that, some mechanical indexes such as triaxial compressive strength, angle of internal friction obtained from under unloading confining tests are greater than those traditional triaxial loading tests. That is to say, there are significant differences in the regularity of the influence of unloading confining pressure on rock mechanical properties.

In this study, the strengths of the sandstone under unloading confining pressure condition are slightly higher than those under triaxial compressive condition on the whole (Fig.11 and 12). This is probably related to the mode of cracks' propagation in sandstone specimens under different stress paths. In the triaxial compressive tests, the lateral deformation of the sample was restricted 
by the confining pressure, and the wing-cracks were hard to propagate freely along the axial direction. Then the coalescence of these cracks formed a shear band, and led to the rupture of the sample (Fig. 13a). In the unloading confining pressure tests, the decrease of confining pressure makes the wing-cracks free propagation along the axial direction (Fig. 13b). It can also be seen from the above failure photographs that the specimens are prone to crack almost parallel to the axial direction under unloading confining pressure condition (Fig. 7a and 8c). Even if there are a large number of cracks along the axis direction, the specimen can still bear the axial loads, as a result, the strengths under unloading confining pressure are generally greater than those under the conventional triaxial compressive condition (Yao et al. 2018).

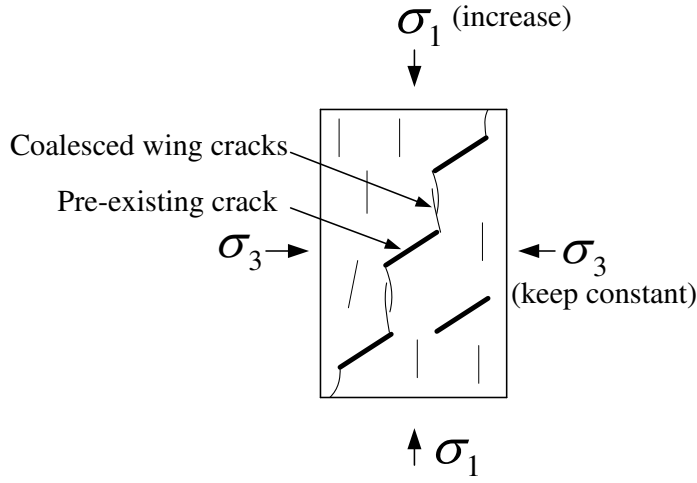

(a) shear mode

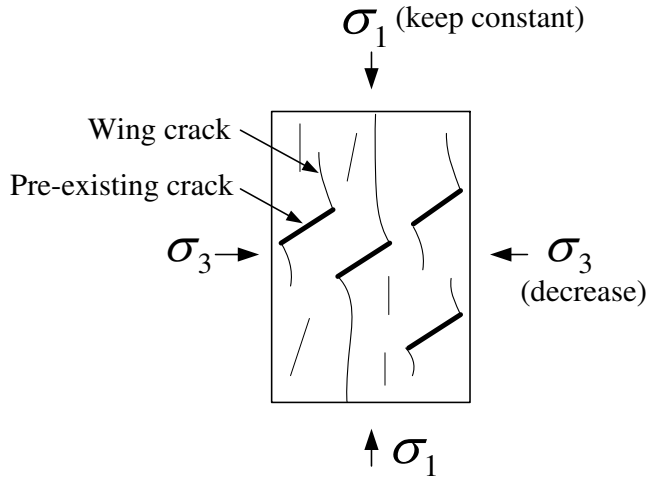

(b) tensile mode

Fig. 13 Schematic diagram of schist failure

\section{Conclusions}

-Water has effects on the strength of the sandstone under conventional triaxial compressive or unloading confining pressure conditions. The compressive strength of sandstone decreases significantly under saturated conditions, and the strength parameters of saturated specimens under unloading confining pressure are also lower than those of dry rock samples. In the process of water saturation, water can weaken the cementation between the grain particles and soften grains boundary, and the clay mineral would expand. The bond and friction characteristics between grain particles are degraded, which leads to the decrease of macroscopic mechanical strengths.

- Water also affects the fracture mode of the sandstone. Under triaxial unloading confining pressure, there are two failure modes of dry sandstone: tension failure and shear failure, while saturated sandstone is mainly shear failure.

- For the sandstone with the same water content, the strengths under triaxial unloading confining pressure is slightly higher than those under triaxial compressive condition. Compared with the stress path of triaxial compression, the stress path of unloading confining pressure makes cracks propagate more easily along the axial direction, and the angle between fracture surface and axial direction is smaller.

\section{Acknowledgements}

The financial support from China Scholar Council (201806695005) is gratefully acknowledged.

\section{References}

Baud P, Zhu W, Wong TF (2000) Failure mode and weakening effect of water on sandstone. J Geophys Res 105(B7):16371-16389

Cai M, Kaiser PK (2005) Assessment of excavation damaged zone using a micromechanics model. Tunn Undergr Space Technol 20(4):301-310 
Chen X, Tang CA, Zhou JF, Cai YY (2018) Experimental investigation on deformation characteristics and permeability evolution of rock under confining pressure unloading conditions. J Cent South Univ 25:1987-2001

Taheri A, Yfantidis N, Olivares C, Connelly B, and Bastian T (2016) Experimental study on degradation of mechanical properties of sandstone under different cyclic loadings Geotech Test J 39(4):673-687

Ciantia MO, Castellanza R, Di Prisco C (2015) Experimental study on the water-induced weakening of calcarenites. Rock Mech Rock Eng 48(2):441-461

Cong Y, Wang Z, Zheng Y, Zhang L (2020) Effect of unloading stress levels on macro- and microfracture mechanisms in brittle rocks. Int J Geomech 20(6):04020066

Dunning J, Douglas B, Miller M, McDonald S (1994) The role of the chemical environment in frictional deformation: stress corrosion cracking and comminution. Pure Appl Geophys 143(1-3):151-178

Erguler ZA, Ulusay R (2009) Water-induced variations in mechanical properties of clay-bearing rocks. Int J Rock Mech Min Sci 46(2):355-370

Fan Y, Lu W, Zhou Y, Yan P, Leng Z, Chen M (2016) Influence of tunneling methods on the strainburst characteristics during the excavation of deep rock masses. Eng Geol 201:85-95

Fu J, Song WD, Tan YY (2018) Study of stability and evolution indexes of gobs under unloading effect in the deep mines. Geomech Eng 14(5):439-451

Ganne P, Vervoort A (2007) Effect of stress path on pre-peak damage in rock induced by macrocompressive and -tensile stress fields. Int J Fracture 144(2)77-89

Li J, Wang L, Wang X, Wang R, Cheng Z, Dang L (2010) Research on unloading nonlinear mechanical characteristics of jointed rock masses. J Rock Mech Geotech Eng 2(4):357-364

Li X, Cao W, Zhou Z, Zou Y (2014) Influence of stress path on excavation unloading response. Tunn Undergr Space Technol 42:237-246

Liu Q, Cheng Y, Jin K, Tu Q, Zhao W, Zhang R (2017) Effect of confining pressure unloading on strength reduction of soft coal in borehole stability analysis. Environ Earth Sci 76:173

Miao J, Jia X, Cheng C (2011) The failure characteristics of granite under true triaxial unloading condition. Procedia Engineering 26:1620-1625

Maruvanchery V, Kim E (2019) Effects of water on rock fracture properties: Studies of mode I fracture toughness, crack propagation velocity, and consumed energy in calcite-cemented sandstone. Geomech Eng 17(1)57-67

Newbrough P, Gammons C (2002) An experimental study of water-rock interaction and acid rock drainage in the Butte mining district, Montana. Environ Geol 41:705-719

Shen B, Barton N (2018) Rock fracturing mechanisms around underground openings. Geomech Eng 16(1):35-47

Swansson SR, Brown WS (1971) An observation of loading path independence of fracture in rock. Int J Rock Mech Min Sci 8(3):277-281

Xu H, Feng XT, Yang C, Zhang X, Zhou Y, Wang Z (2019) Influence of initial stresses and unloading rates on the deformation and failure mechanism of jinping marble under true triaxial compression. Int $\mathrm{J}$ Rock Mech Min Sci 117:90-104

Yang SQ, Jing HW, Li YS, Han LJ (2011) Experimental investigation on mechanical behavior of coarse marble under six different loading paths. Exp Mech 51(3):315-334

Yao HY, Jia SP, Li HG (2018) Experimental study on failure characteristics of schist under unloading condition. Geotech Geol Eng 36(2):905-913

Zhang Y, Ding X, Huang S, Wu Y, He J (2020) Strength degradation of a natural thin-bedded rock mass subjected to water immersion and its impact on tunnel stability. Geomech Eng 21(1):63-71

Wasantha PLP, Ranjith PG, Permata G, Bing D (2018) Damage evolution and deformation behaviour of dry and saturated sandstones: insights gleaned from optical measurements. Measurement 130:8-17

Wang JJ, Liu MN, Jian FX, Chai HJ (2019) Mechanical behaviors of a sandstone and mudstone under loading and unloading conditions. Environ Earth Sci 78:30

Wang H, Dyskin A, Dight P, Pasternak E, Hsieh A (2020) Review of unloading tests of dynamic rock failure in compression. Eng Fracture Mech 225:106289 
Figures

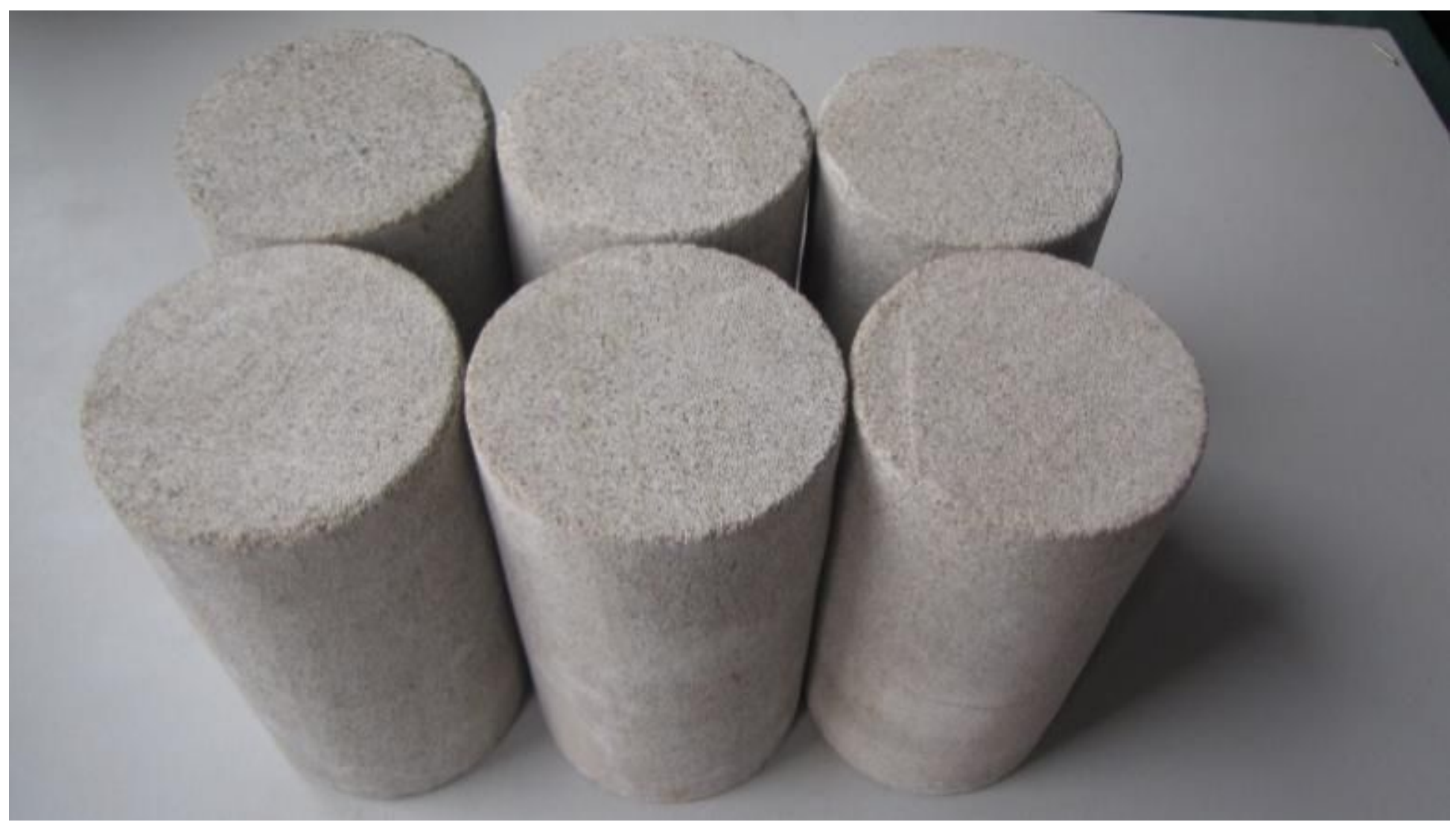

Figure 1

Specimens prepared

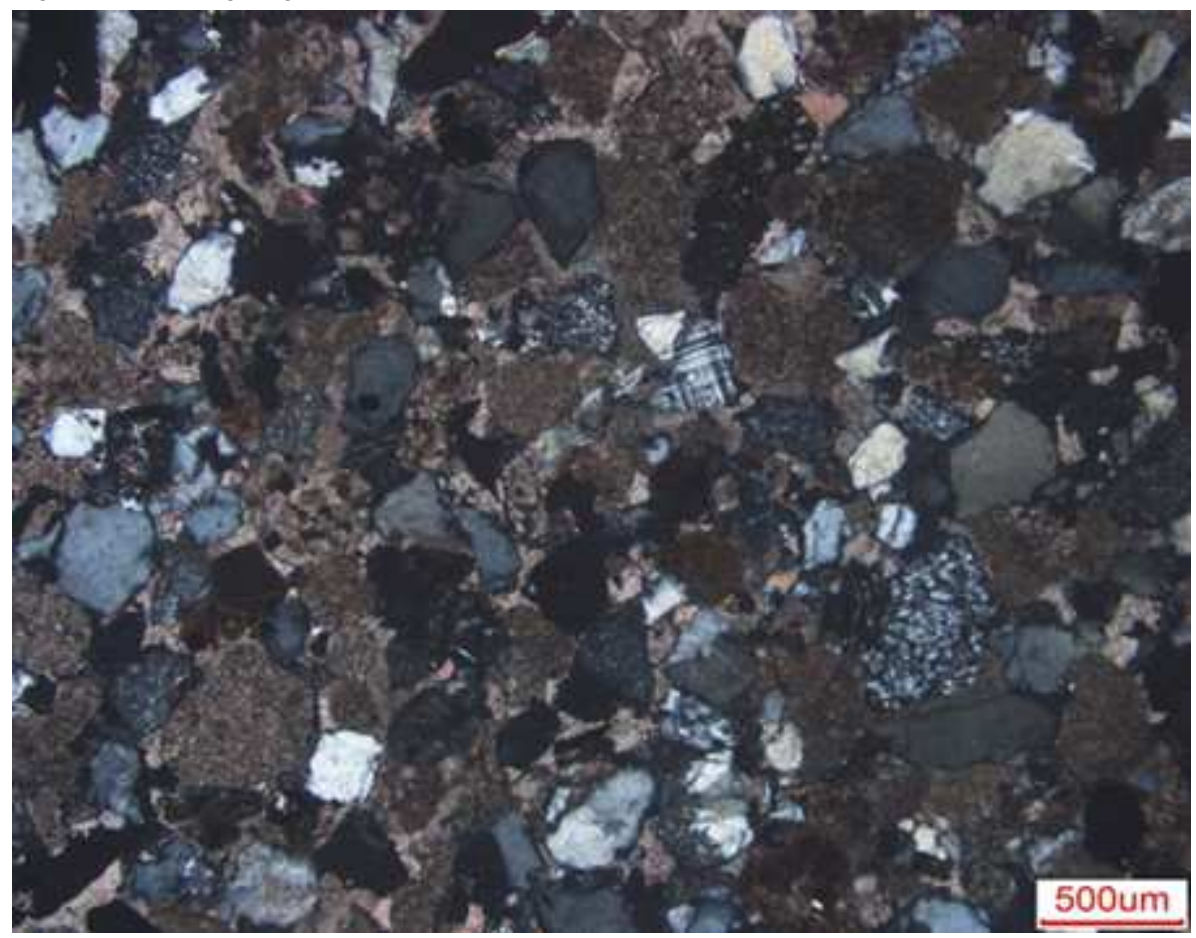

Figure 2 
The microscopic photograph of the sandstone

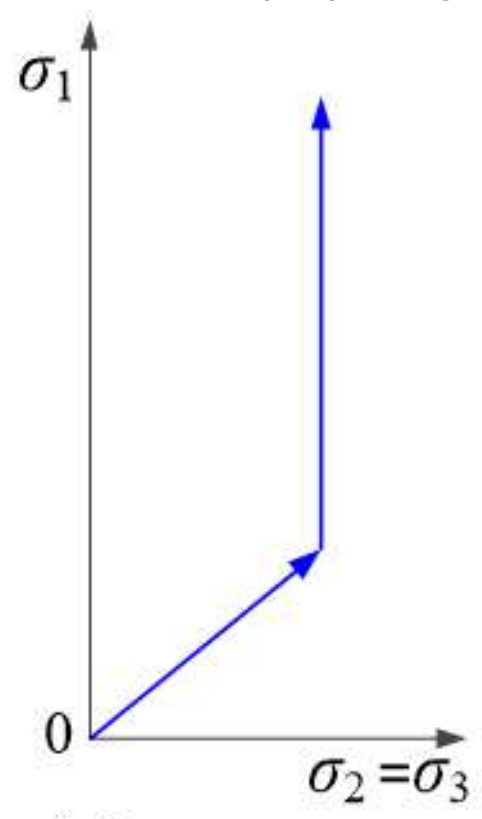

(a)

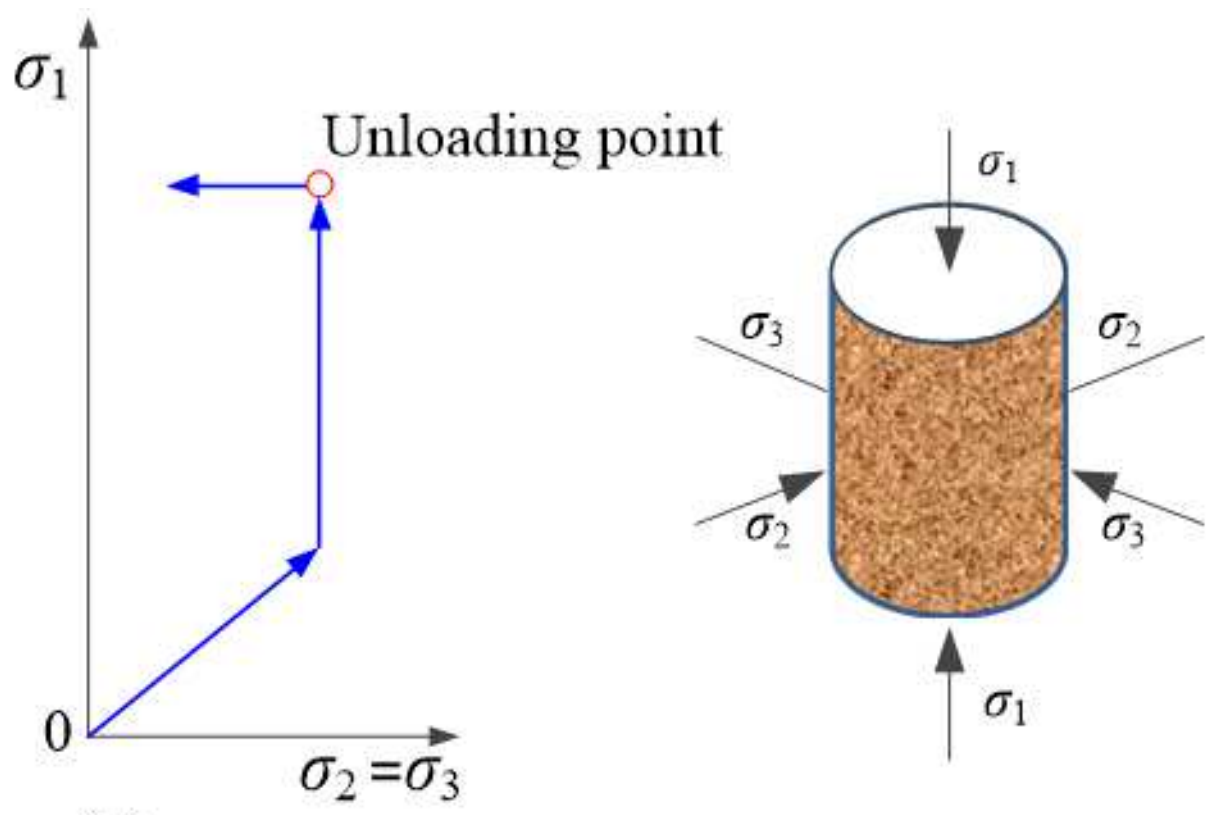

(b)

Figure 3

Graphical of stress paths:(a) conventional triaxial loading test; (b) unloading confining pressure.
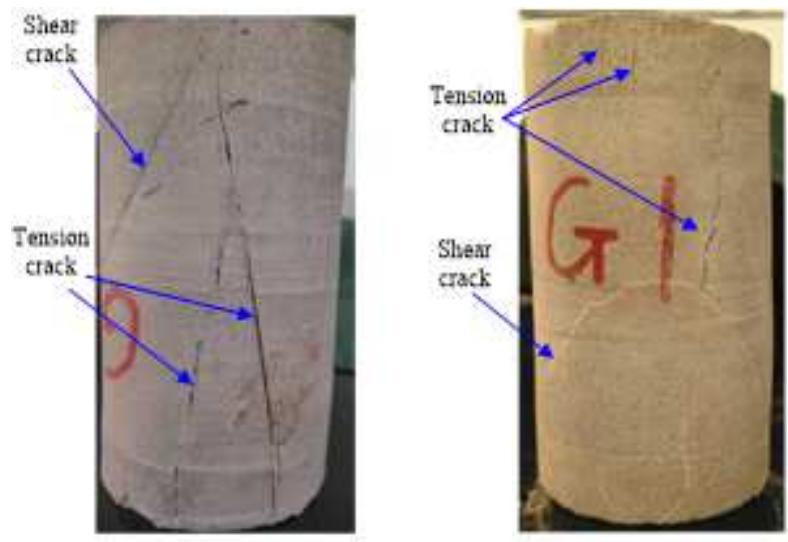

Figure 4

Failure diagram of G1 


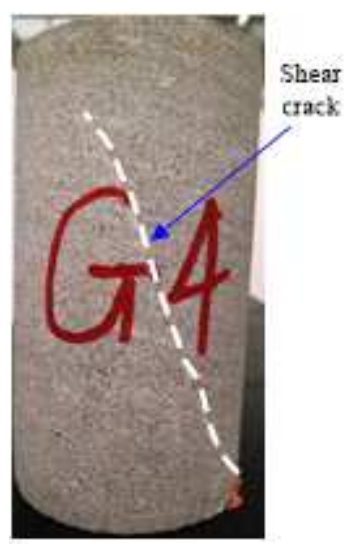

\section{Figure 5}

Failure diagram of G4

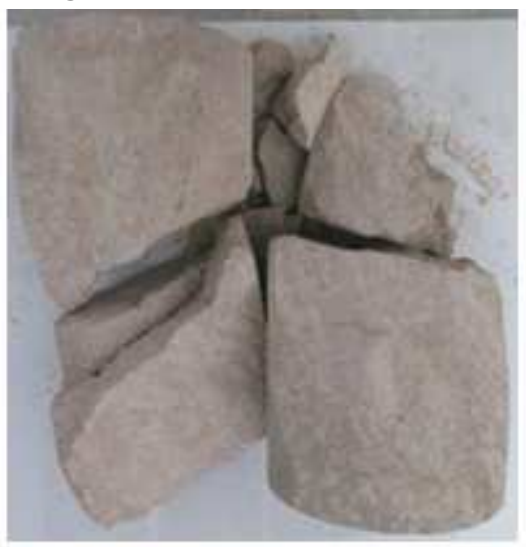

(a) $\mathrm{S} 1$ specimen under the confining pressure of $5 \mathrm{MPa}$

\section{Figure 6}

Failure diagram of the saturated specimens

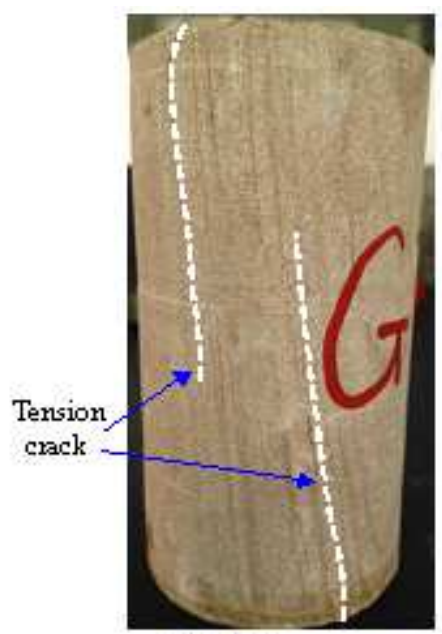

(a) G7

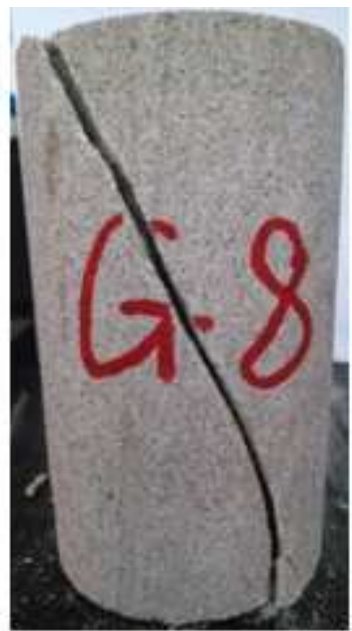

(b) G8 
Figure 7

Failure diagram of dry specimens

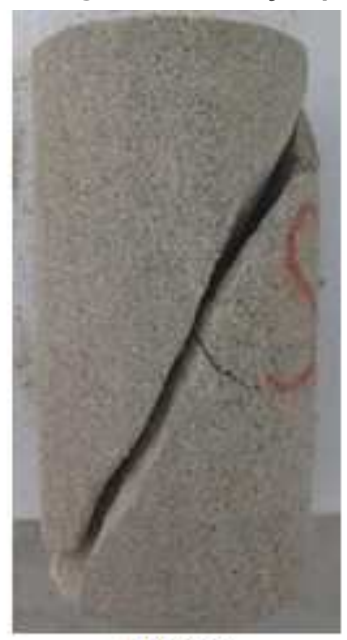

(a) $\mathrm{S} 6$

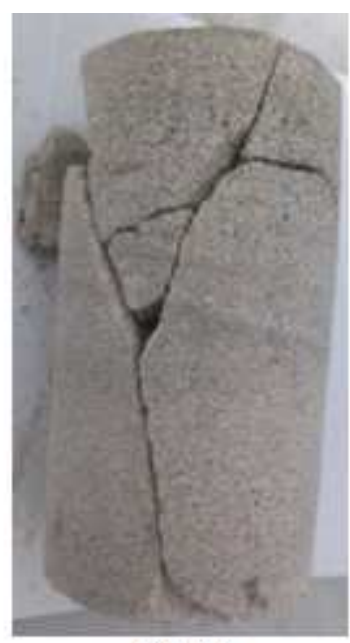

(b) S7

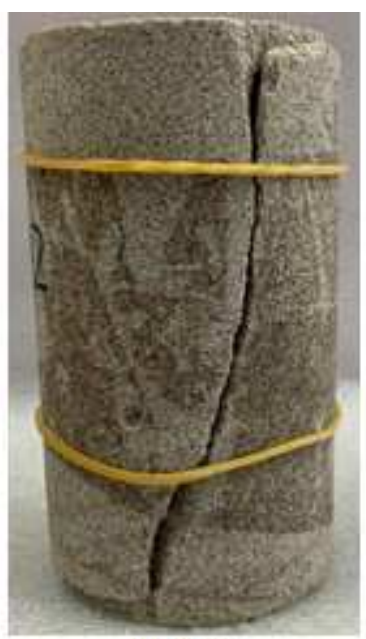

(c) $\mathrm{S} 12$

\section{Figure 8}

Failure diagram of saturated specimens

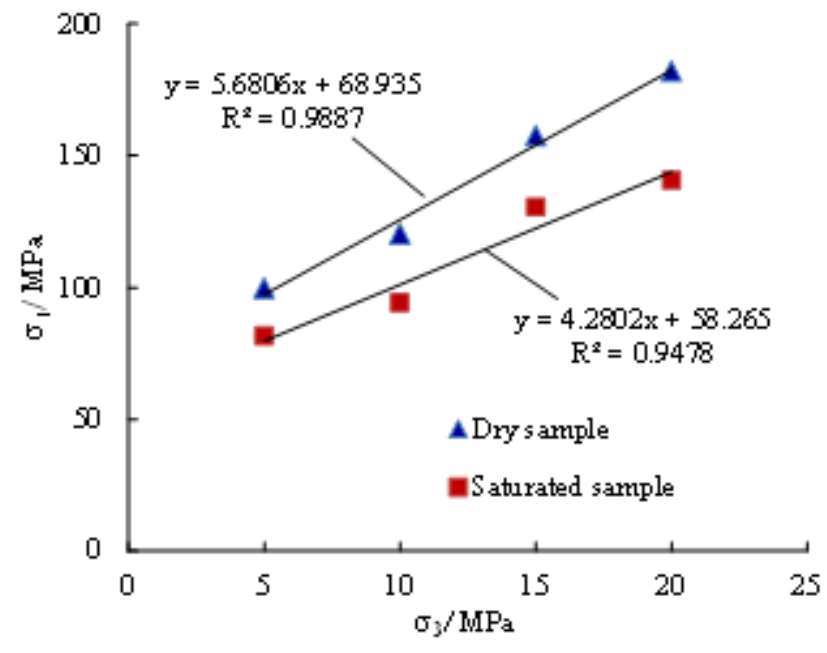

Figure 9

Relationships between peak strength and confining pressure of saturated and dry specimens under conventional triaxial loading test 


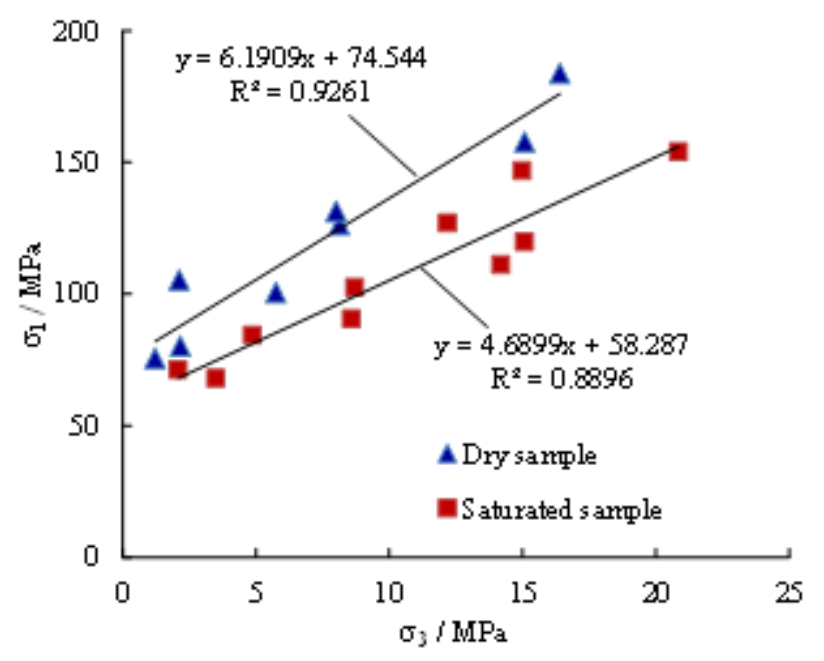

Figure 10

Relationships between axial peak and confining pressures of the saturated and dry specimens under unloading confining pressure test

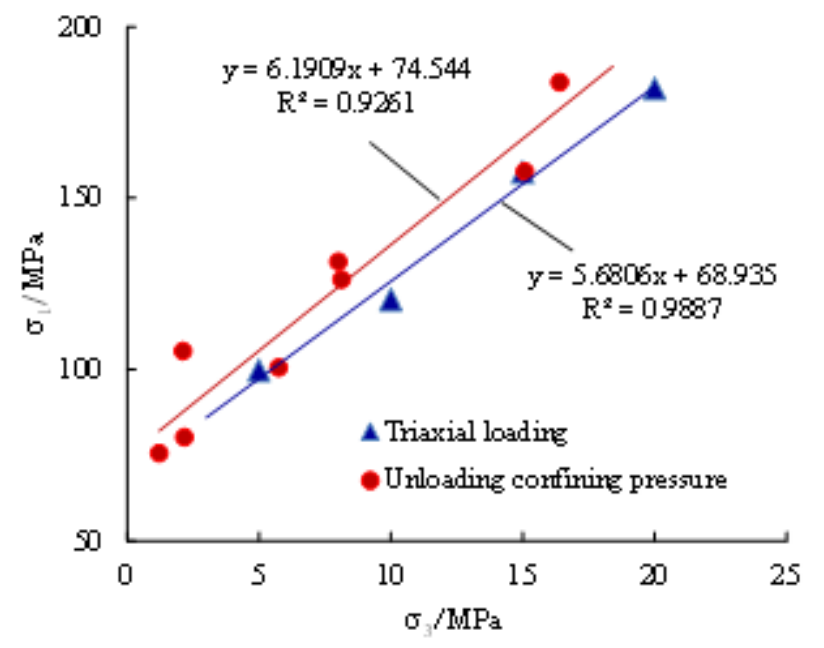

Figure 11

Relationships between peak and confining pressure of dry specimens under triaxial loading and unloading 


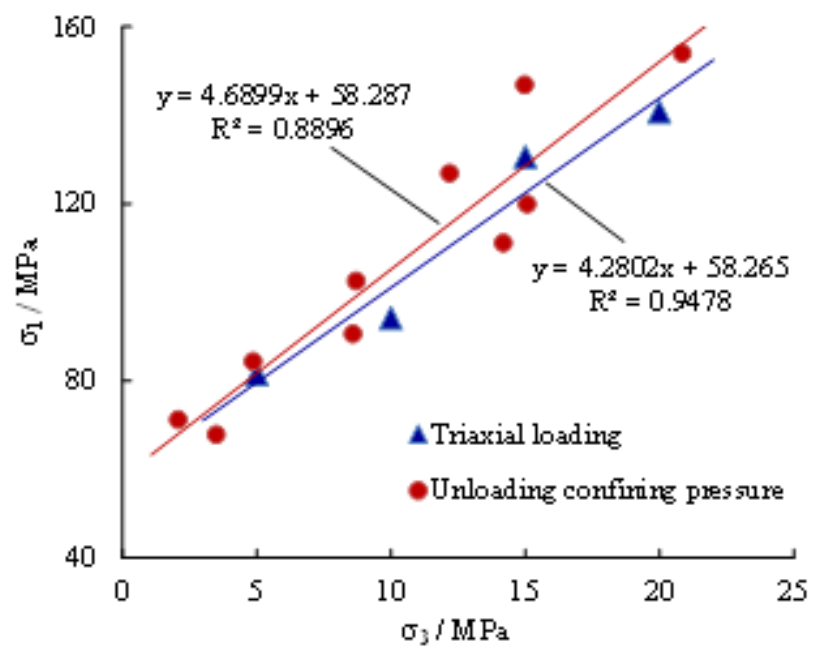

Figure 12

Relationships between peak and confining pressure of saturated specimens under loading and unloading

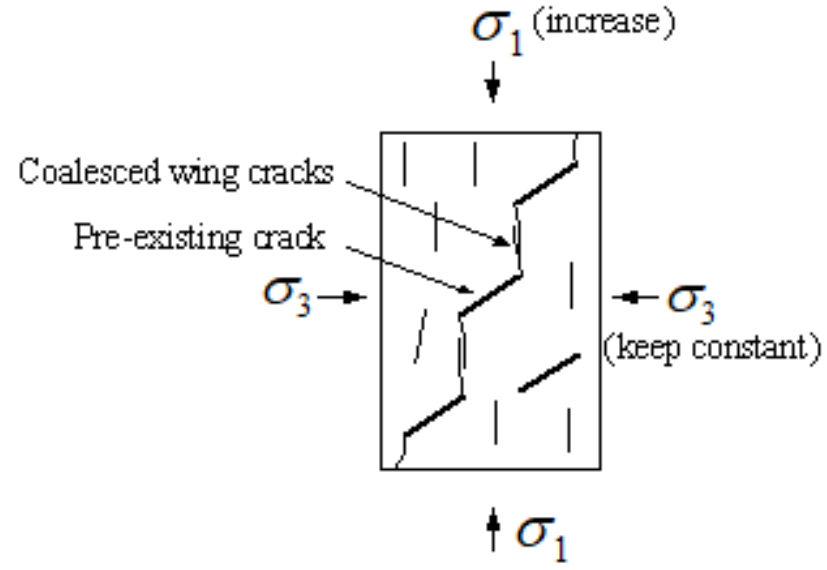

(a) shear mode

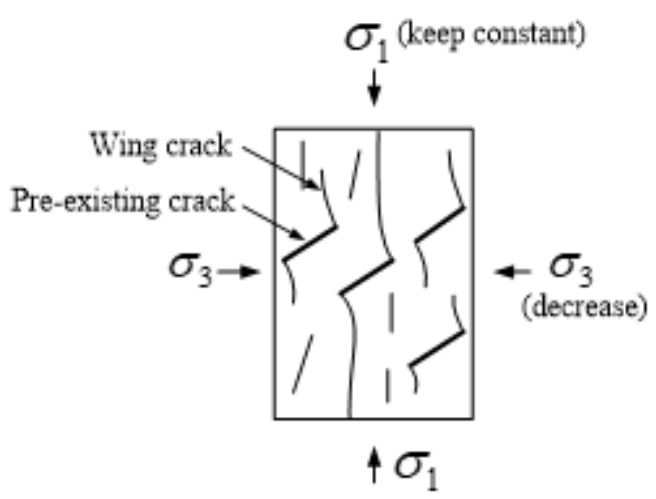

(b) tensile mode

\section{Figure 13}

Schematic diagram of schist failure 